\title{
Keterbukaan Informasi Publik pada Konsil Kedokteran Indonesia
}

\author{
Leila Mona Ganiem
}

Program Magister Ilmu Komunikasi Universitas Mercubuana

Jl. Meruya Selatan No. 1, Kembangan, Jakarta Barat - Indonesia

Correspondent author: leila.mona@mercubuana.ac.id

\begin{abstract}
Abstrak
Transparansi terhadap informasi adalah salah satu pelaksanaan demokrasi suatu negara. Melalui keterbukaan informasi, publik memperoleh kesempatan untuk menikmati hasil kemajuan negara dan berpartisipasi untuk mewujudkan kesejahteraan masyarakat. Undang-Undang Nomor 14 Tahun 2018 tentang Keterbukaan Informasi Publik (KIP) mengamanahkan agar badan publik yang berkaitan dengan penyelenggaraan negara membuka informasi yang berkaitan dengan kepentingan publik. Salah satunya Konsil Kedokteran Indonesia (KKI). Beberapa tantangan terhadap akses informasi publik yang dihadapi oleh Komisi Informasi sedunia dirasakan oleh sejumlah lembaga di dunia, termasuk masalah keamanan data yang merupakan salah satu kejahatan besar di Indonesia. Tujuan penelitian adalah untuk mengetahui bagaimana KKI mengelola keterbukaan informasi publik dan upaya apa saja yang dilakukan oleh KKI dalam menjaga keamanan data KKI. Metode penelitian dilakukan dengan deskriptif kualitatif. Pengumpulan data secara primer dengan interview dan sekunder dengan kajian dokumen, teks, hasil presentasi, regulasi terkait. Hasilnya, bentuk keterbukaan informasi publik dari KKI dilakukan secara hati-hati meliputi Informasi Publik Berkala, Informasi Publik Serta Merta, Informasi Publik Setiap Saat, Informasi Publik Kecuali (ketat terbatas dan rahasia). Upaya menjaga keamanan informasi KKI dilakukan dengan cara: mengacu pada pasal 27, Perkonsil No 18 Tahun 2014 Tentang Sistem Informasi Registrasi Dokter dan Dokter Gigi Berbasis Elektronik; penggunaan sistem registrasi internal yang dimiliki dan dioperasikan sendiri; memperoleh ISO 9001:2008 yaitu Sistem Manajemen Mutu dan Budaya Organisasi Pelayanan Publik; Berikutnya, KKI juga menerapkan penomoran yang unik bekerja sama dengan Badan Siber dan Sandi Negara terkait pemanfaatan sertifikat elektronik pada sistem elektronik di KKI.
\end{abstract}

Kata Kunci: Keamanan data, Keterbukaan Informasi Publik, Lembaga Negara.

\begin{abstract}
Transparency of information is one of the implementations of a country's democracy. Through information disclosure, the public gets the opportunity to enjoy the results of the country's progress and participate in realizing public welfare. Law No. 14 of 2018 concerning Public Information Openness (KIP) mandates that public bodies relating to the administration of the state disclose information relating to the public interest. One of them is the Indonesian Medical Council (KKI). Some challenges to access to public information faced by the World Information Commission are felt by a number of institutions in the world, including data security issues which are one of the major crimes in Indonesia. The purpose of the study was to find out how KKI manages public information disclosure and what efforts have been made by KKI in maintaining the security of KKI data. The research method was carried out with qualitative descriptive. Primary data collection by interview and secondary by reviewing documents, texts, presentation results, related regulations. As a result, the form of public information disclosure from KKI is carried out carefully including Periodic Public Information, Public Information and Merta, Public Information at Any Time, Except Public Information (strictly limited and confidential). Efforts to safeguard KKI information security are carried out by: referring to article 27, Perconsil No. 18 of 2014 concerning Electronic-Based Doctor and Dentist Registration Information Systems; use of an internal registration system that is owned and operated by itself; obtain ISO 9001: 2008, namely the Public Service Organization Quality and Culture Management System; Next, KKI also applies unique numbering in collaboration with the National Cyber and Code Body related to the utilization of electronic certificates on electronic systems in KKI.
\end{abstract}

Keywords: Data Security, Public Information Openness, State Institutions.

Copyright @ 2018 Ikatan Sarjana Komunikasi Indonesia. All rights reserved 


\section{PENDAHULUAN}

Kedaulatan sebuah negara dilihat dari kemampuan menjaga keutuhan wilayah dan isi di dalamnya. Penjagaan terhadap kedaulatan negara selayaknya tidak mengurangi hak-hak warga negara atas informasi. Akses terhadap informasi merupakan kunci demokrasi (Carter Center, 2002). Negara yang menjalankan prisip pengelolaan negara yang baik, akan memberikan kesempatan pada warga negara untuk mengetahui kinerja pemerintah dan bahkan ikut mengontrol kinerja mereka.

Di masa Orde Baru, dengan alasan kerahasiaan, informasi dikontrol pemerintah. Ketika sebuah informasi akan disajikan media maka hal itu akan dilakukan melewati proses pengawasan yang ketat.

Keterbukaan informasi dari penyelenggara negara kian nyata dilakukan sejak masa reformasi 1998. Saat itu, kesadaran akan informasi sebagai hak asasi manusia kian didorong. Diyakini juga bahwa hak atas informasi merupakan salah satu komponen penting dari sebuah tatanan bernegara. Keterbukaan informasi pada publik merupakan bagian dari tanggung jawab lembaga negara dan pemerintah dalam penyelenggaraan pelayanan publik yang juga merupakan hak bagi warga negara, bahkan sebagai pembuka akses terhadap hak-hak lainnya. Transparansi informasi yang diperoleh dengan tepat dan sesuai, memungkinkan publik memperoleh kesempatan untuk menikmati hasil kemajuan negara dan bahkan berpartisipasi untuk mewujudkan kesejahteraan masyarakat. Untuk itu pada tahun 2008, negara membuat Undang-Undang Nomor 14 tentang Keterbukaan Informasi Publik (KIP).

Dalam pertimbangan lahirnya Undang-Undang KIP No 14 Tahun 2008, disebutkan bahwa: a) informasi merupakan kebutuhan pokok setiap orang bagi pengembangan pribadi dan lingkungan sosialnya serta merupakan bagian penting bagi ketahanan nasional; b) bahwa hak memperoleh informasi merupakan hak asasi manusia dan keterbukaan informasi publik merupakan salah satu ciri penting negara demokratis yang menjunjung tinggi kedaulatan rakyat untuk mewujudkan penyelenggaraan negara yang baik; c) bahwa keterbukaan informasi publik merupakan sarana dalam mengoptimalkan pengawasan publik terhadap penyelenggaraan negara dan Badan Publik lainnya dan segala sesuatu yang berakibat pada kepentingan publik; d) bahwa pengelolaan informasi publik merupakan salah satu upaya untuk mengembangkan masyarakat informasi.

Dasar-dasar pertimbangan Undang-Undang KIP tersebut secara kuat juga dilandasi oleh Pasal 20, Pasal 21, Pasal 28 F, dan Pasal 28 J UndangUndang Dasar Negara Republik Indonesia Tahun 1945. Disamping itu, secara internasional, deklarasi umum Hak Asasi Manusia (DUHAM) Pasal 19; UU No. 39 Tahun 1999 tentang Hak Asasi Manusia, pasal 14; UU No. 12 Tahun 2005 tentang Ratifikasi Kovenan Internasional Hak-hak Sipil Politik. Pasal 19, Ayat 2 juga mendukung keterbukaan informasi publik.

Pelaksanaan terhadap keterbukaan informasi publik di berbagai negara, tidak senantiasa mulus. Pada pertemuan komisioner Komisi Informasi sedunia (ICIC) 2015, di Santiago, Chile, yang dihadiri oleh 25 negara, dinyatakan bahwa terdapat tantangan terhadap akses informasi publik, yaitu: (1) Berlanjutnya ketidaksetaraan, yang membatasi hak atas akses informasi kepada semua warga negara; (2) Memburuknya hak atas akses informasi yang disebabkan dikeluarkannya legislasi dan kebijakan publik yang bertentangan dengan hak tersebut; (3) Dilemahkannya hak atas akses informasi dengan menggunakan teknologi baru; (4) Kurangnya anggaran, dukungan dan penguatan lembaga yang menangani akses informasi. Untuk itu, maka perlu bagi pemerintah, organisasi masyarakat sipil, komunitas internasional, dan warga negara untuk tetap waspada dan bekerja 
bersama untuk melindungi, mempromosikan, dan memperkuat cara yang efektif untuk mendapatkan hak atas akses informasi.

Implementasi Undang-Undang Keterbukaan Informasi Publik dilaksanakan oleh badan publik. Salah satunya adalah Konsil Kedokteran Indonesia (KKI) sebagai lembaga negara. KKI adalah badan otonom, mandiri, non struktural dan bersifat independen, yang bertanggung jawab kepada Presiden RI, dan merupakan amanah UU Praktik Kedokteran No 29 Tahun 2014. Di dalam Peraturan Konsil (Perkonsil) Nomor 18 Tahun 2014 tentang Sistem Informasi Registrasi Dokter dan Dokter Gigi Berbasis Elektronik, KKI memberikan penjelasan mengenai informasi yang disediakan untuk publik.

Di lingkup yang lebih luas, terdapat kesepakatan yang memandu KKI dalam berbagi informasi. Misalnya, Piagam Mutual Recognition Agreement ASEAN yang telah diratifikasi Pemerintah pada Undang-Undang no 38 Tahun 2008 berimplikasi pada kesepakatan diantara Konsil Kedokteran ASEAN dan Badan Disiplin Medis (Medical Disciplinary Board) di ASEAN.

Terkait dengan AFAS (ASEAN Framework Agreement on Services) negara- negara ASEAN menyepakati 7 jasa profesi yang diliberalisasi, diantaranya dokter (5 kompetensi) dan dokter gigi. Kesepakatan pada MRA ASEAN adalah pertukaran informasi, memfasilitasi mobilitas dan peningkatan kapasitas (capacity building). Pertukaran informasi yang dimaksud adalah publikasi melalui website.

Lebih lanjut, kesepakatan dari Medical Disciplinary Board ASEAN pada bulan April 2014, menghasilkan komitmen, diantaranya yang terkait dengan keterbukaan informasi adalah: a). Semua anggota ASEAN sepakat saling berbagi informasi tentang kriteria pelanggaran disiplin serta proses penegakan disiplin di website setiap negara; b). Semua negara ASEAN sepakat untuk tidak mempublikasikan dokter/dokter gigi yang telah melakukan pelanggaran disiplin.

Kini, teknologi informasi menjadi panduan yang mendominasi berbagai kegiatan individu, masyarakat, korporasi dan lembaga negara. Keterbukaan informasi publik juga memanfaatkan perkembangan teknologi informasi tersebut.

Prediksi akan dampak perkembangan teknologi komunikasi dan informasi ini telah dibahas dalam suatu pertemuan UNESCO tahun 1969 di Montreal (Changara, 2013:6-7). Pertemuan tersebut menghasilkan pembahasan, diantaranya: (1). Masalah-masalah komunikasi yang erat hubungannya dengan kebebasan arus informasi dan bahaya imperialism budaya bisa meracuni tatanan social negara-negara sedang berkembang; (2). Kemajuan teknologi komunikasi yang begitu cepat terutama dengan kehadiran teknologi satelit yang dikhawatirkan dapat merusak dan melanggar kedaulatan banyak negara.

Disamping itu, kekhawatiran yang perlu untuk dipertimbangkan juga adalah adanya ancaman pada kedaulatan negara akibat adanya globalisasi informasi ini. Hal ini karena lembaga negara saat ini, berbagai informasi disampaikan melalui transaksi online, termasuk penyimpanan data dan registrasi dokter/dokter gigi dilakukan secara online. Karena itu, kondisi keamanan sistem informasi dan komunikasi di Indonesia perlu mendapat perhatian serius. Berdasarkan riset "e-Marketer" (November 2014), dari 25 top pengguna internet dunia. Indonesia adalah negara dengan peringkat keenam dunia yang rawan kejahatan siber, setelah China, Amerika Serikat, India, Brasil dan Jepang. Laporan ATKearney (2018), sebuah perusahaan konsultan manajemen yang berkantor di lebih dari 40 negara, juga memuat kesimpulan bahwa wilayah ASEAN adalah target utama dari serangan siber.

Indonesia Security Incident Response Team on Internet Infratructure (ID-SIRTII) memprediksi pada 2014 ada 48 juta serangan siber di Indonesia. Ini berarti, terdapat kira-kira 100 serangan dilakukan oleh peretas setiap menitnya di Tanah Air. Menurut Bareskim, dalam kurun 
waktu 3 tahun terakhir, tercatat 36,6 juta serangan kejahatan siber terjadi di Indonesia. Total kerugian kejahatan siber di Indonesia mencapai Rp. 33,29 Miliar.

Menilik pada potensi kejahatan siber, kita dapat temukan diantaranya penjebolan sistem dan pencurian data hingga penyadapan, peretasan sistem dan pengambilan data. Ini semua merupakan sebuah refleksi yang perlu mendapat perhatian pemerintah Indonesia karena sebuah lembaga Negara dapat dengan mudah disusupi oleh pihak yang tidak bertanggung jawab.

Sebuah berita mengejutkan pada negara yang sangat peduli pada keamanan siber, yaitu Singapura, pada bulan Juni 2018 mengalami kebocoran data terbesar tentang data personal dan informasi kesehatan terhadap 1,5 juta orang termasuk Perdana Menteri Singapura, Lee Hsien Loong. Sebagai lembaga negara, KKI memiliki tanggung jawab untuk memberikan informasi kepada publik secara terbuka. Sejauh mana pelaksanaan keterbukaan informasi publik telah dijalankan oleh KKI sebagai lembaga negara yang berhubungan dengan konteks kedokteran yang memiliki regulasi khas terhadap privasi data.

Selain itu, perkembangan teknologi informasi dan komunikasi yang kini berada di Industri 4.0, membuat berbagai hal terhubung secara online. Tantangannya, di era kemajuan teknologi komunikasi yang begitu pesat, transmisi informasi menggunakan siber, memiliki potensi besar dalam penyimpangannya. Meski demikian, tidak ada satupun peralatan yang dibuat dengan menggunakan aplikasi pemrograman yang tidak ada celah masalah keamanannya, karena itu perlu ada upaya strategis dalam menjaga keamanan siber. Selain itu, tak jarang, sistem informasi yang sangat mahal dan canggih, namun lupa memfasilitasi sistem tersebut dengan pengamanan yang canggih. Artinya, komunikasi tidak hanya dapat dilihat sebagai fenomena mekanistis, matematis dan informatif seperti yang dijabarkan oleh teori klasik karya Shannon dan Weaver (1949), upaya serius dalam penjagaan keamanan data, perlu dilakukan dalam upaya mempertahankan kedaulatan Indonesia.

Karena itu, penelitian ini ditujukan untuk mengetahui: (1) Bagaimana upaya KKI dalam memberikan informasi pada publik sesuai UU KIP No 14 Tahun 2008, (2) Upaya apa saja yang dilakukan oleh KKI dalam menjaga keamanan data KKI.

\section{KERANGKA TEORITIS}

Komunikasi sederhananya 'siapa berbicara apa dalam saluran yang mana kepada siapa dan pengaruh seperti apa' (Lasswell, 1948). Dalam hal ini, informasi (apa) disalurkan oleh KKI (siapa) kepada pihak yang dituju yaitu publik. Informasi adalah data yang telah diproses dalam suatu bentuk yang mempunyai arti bagi penerima dan memiliki nilai nyata yang dibutuhkan untuk proses pengambilan keputusan saat ini maupun saat yang akan datang (Gordon B. Davis 1995). Merujuk pada pendapat Lasswell, maka pengaruh dari adanya informasi dapat berhubungan dengan pengambilan keputusan oleh masyarakat dalam memperoleh kesejahteraannya.

Penyebaran informasi yang merupakan hasil inovasi atau gagasan dari KKI bagi kepentingan masyarakat, dikomunikasikan pada publik melalui berbagai saluran dan dan jangka waktu tertentu dalam sebuah sistem sosial. Informasi ini merupakan bentuk transparansi dalam pemerintah. Transparansi merupakan nilai instrinsik dari masyarakat demokratis. Di banyak kajian, keterbukaan tersebut dianggap meningkatkan akuntabilitas dan kepercayaan (Erna Ruijer, 2013).

Transparansi pemerintah melalui keterbukaan informasi telah banyak dikaji dalam penelitian, antara lain Retnowati, yang meyakini pentingnya pemerintah menyiapkan sarana prasarana, sumber daya manusia yang punya kemampuan (skill) dan kemauan serta komitmen dari seluruh penyelenggara pemerintahan atau badan publik dan aparat atau komponennya untuk melaksanakan keterbukaan informasi publik (Retnowati, 2012). Penelitian Nupikso terkait 
Implementasi Keterbukaan Informasi Publik dalam Website Pemerintah Daerah menyimpulkan bahwa secara umum, kuantitas muatan informasi publik yang ditampilkan dalam website pemerintah masih rendah, meskipun beberapa website memperoleh poin tinggi dalam beberapa indikator (Nupikso, 2015).

Riset yang mengupas kesulitan dalam implementasi UU KIP dilakukan oleh Irianto dan Ispriyarso. Menurut mereka keterbukaan informasi publik di Perbankan yang menjadi penggerak sektor ekonomi mengalami kesulitan mengingat produk hukum keterbukaan informasi publik ini bertentangan dengan prinsip etika dalam perbankan (khususnya keterbatasan pemberian keterangan) dan produk hukum lainnya (Irianto dan Ispriyarso (2016). Berbagai benturan kepentingan dalam keterbukaan informasi publik memerlukan upaya mitigasi risiko secara komprehensif. Penelitian terdahulu tersebut menjadi inspirasi dari penelitian ini.

Informasi yang dibuka pada publik dalam definisi di Undang-Undang Keterbukaan Informasi Publik No 14 tahun 2008 adalah keterangan, pernyataan, gagasan dan tanda-tanda yang mengandung nilai, makna dan pesan baik data, fakta maupun penjelasannya yang dapat dilihat, didengar dan dibaca yang disajikan dalam berbagai kemasan dan format sesuai dengan perkembangan teknologi informasi dan komunikasi secara elektronik ataupun nonelektronik.

Undang-Undang tentang Keterbukaan Informasi Publik mempunyai asas: (1). setiap informasi publik bersifat terbuka dan dapat diakses oleh setiap pengguna informasi publik; (2). informasi publik yang dikecualikan bersifat ketat dan terbatas; (3). Setiap informasi publik harus dapat diperoleh setiap pemohon informasi publik dengan cepat dan tepat waktu, biaya ringan dan cara sederhana; dan (4). Informasi publik yang dikecualikan bersifat rahasia sesuai dengan Undang-Undang, kepatutan dan kepentingan umum didasarkan pada pengujian tentang konsekuensi yang timbul apabila suatu informasi diberikan kepada masyarakat serta setelah dipertimbangkan dengan seksama bahwa menutup informasi publik dapat melindungi kepentingan yang lebih besar daripada membukanya atau sebaliknya.

Keterbukaan informasi yang disampaikan pada publik dapat dalam bentuk elektronik dan nonelektronik. Secara elektronik, informasi dibagi melalui network internasional dari komputer yang terkoneksi (internet atau international network of interconnected computers) (Reno v. ACLU, 1997). Pengaplikasian sistem elektronik dewasa ini kian memudahkan efisiensi informasi.

Kemudahan berkomunikasi dan bertransaksi kini semakin terbuka melintasi ruang dan waktu. Bagai sisi mata uang, ada manfaat positif dan dampak negatif. Produk dari perkembangan teknologi itu sendiri menghasilkan kreativitas kejahatan yang baru, yaitu kejahatan siber (cybercrime).

Cybercrime dibagi menjadi dua kategori (Shinder (2002: 19. Pertama, kejahatan siber yang dapat menciptakan korban kekerasan baik pada masyarakat, keluarga, individu atau anak-anak. Kejahatan ini meliputi terorisme internet (cyberterorism), serangan dengan ancaman misal melalui email (assault by threat), penguntitan di internet (cyberstalking) atau pornografi anak (child pornography);

Kedua, kejahatan komputer tanpa kekerasan yang meliputi memasuki jaringan tanpa adanya kewenangan (cybertrespass); penggelapan uang atau property yang dipercayakan atau yang tidak dipercayakan melalui komputer, pencurian rahasia dagang, plagiat, mengkopi secara tidak sah perangkat lunak seni, penggunaan identitas orang lain untuk melakukan kejahatan, penyusupan untuk mengubah data korban, menyembunyikan alat penghubung ke dalam sistem komputer secara diam-diam untuk dipelajari kemudian dicuri yang secara keseluruhan masuk kategori pencurian (cybertheft); penjualan online yang menipu (cyberfraud); pengerusakan yang menganggu jaringan pelayanan seperti menambah, mengurangi, mengubah data atau instruksi pada program secara tidak 
sah (destructive cybercrimes); dan kejahatan komputer nonkekerasan seperti iklan internet prostitusi, perjudian, penjualan narkotika, pencucian uang (other nonviolent cybercrimes).

Atas tingginya peluang terjadinya kejahatan siber, maka perlu ada sistem yang mencegahnya sehingga masyarakat dapat memperoleh sebesar-besarnya manfaat positif dari keterbukaan informasi tersebut.

\section{METODE PENELITIAN}

Penelitian ini bersifat Deskriptif dan Kualitatif. Pertimbangan yang melandasi dipilihnya penelitian bersifat deskriptif adalah karena penelitian ini ditujukan untuk memahami masalah terkait keterbukaan informasi publik pada data terkait dokter dan dokter gigi di KKI, tanpa bermaksud menguji kekuatan hubungan antara hal-hal yang membentuk persepsi tersebut. Selanjutnya, desain kualitatif dalam penelitian ini sesuai dengan pandangan Miles dan Huberman, yaitu ingin memahami keunikan yang terdapat pada isu yang diamati secara menyeluruh, rinci, dalam dan dapat dipertanggungkawabkan secara ilmiah (Miles dan Huberman, 1994: 6-7). Penelitian ini juga dimaksudkan untuk mendapatkan pemahaman terkait realitas yang diteliti dari perspektif informan.

Data pada penelitian ini menggunakan data primer dan sekunder. Secara primer, dilakukan dengan cara: Interview. Dalam hal ini peneliti memperoleh informasi terkait realitas yang diteliti dengan cara bertanya langsung kepada responden. Informan yang peneliti mintai keterangan diseleksi hanya pihak yang benar-benar memiliki pemahaman dan kompetensi atas isu terkait kebijakan data di KKI. Informan yang diteliti sejumlah delapan orang pemegang keputusan di KKI atau MKDKI, baik periode sekarang maupun sebelumnya; Informan dari secretariat KKI serta, NHD, Praktisi di bidang Teknologi informasi, bekerja di perusahaan IT Nasional.

Selain interview, peneliti juga melakukan kajian pada kokumen, teks atau catatan tertulis yang diantaranya Newsletter terbitan KKI terkait Keterbukaan Informasi Publik, Undang-Undang, kebijakan dan kesepakatan legal lainnya. Peneliti juga melakukan studi mendalam atas isu tersebut.

Unit analisis dalam penelitian ini adalah lembaga yaitu Konsil Kedokteran Indonesia. Objek penelitian adalah website dan dokumen yang dimiliki oleh KKI, Undang-Undang Keterbukaan Informasi Publik, data BSSN, data Kominfo dan data pendukung lainnya.

Analisis data dalam penelitian ini dilakukan dengan beberapa langkah, yaitu: peneliti mengolah data mentah melalui wawancara, data teks serta studi mendalam terhadap dokumen Peraturan-Peraturan, laporan penyelenggaraan, rekaman suara hasil wawancara dan catatan tertulis. Selanjutnya peneliti mentranskrip data, mengubah rekaman suara dalam bentuk tertulis. Peneliti melakukan koding untuk memperoleh informasi yang penting hasil pilahan dari data yang dimiliki. Berikutnya peneliti melakukan ketegorisasi data, penarikan kesimpulan. Untuk memastikan data yang diperoleh mewakili informasi yang diinginkan, maka peneliti melakukan triangulasi dengan mengecek sebuah sumber data dengan sumber data lainnya. Atas perolehan data tersebut, peneliti menyimpulkan hal-hal utama sebagai temuan dalam penelitian ini.

\section{HASIL PENELITIAN}

Konsil Kedokteran Indonesia atau KKI merupakan suatu badan otonom, mandiri, non struktural dan bersifat independen, yang bertanggung jawab kepada Presiden RI. KKI didirikan pada tanggal 29 April 2005 di Jakarta yang anggotanya terdiri dari 17 (tujuh belas) orang komisioner. KKI mempunyai fungsi, dan tugas yang diamanatkan dalam pasal 7 Undang-undang Praktik Kedokteran nomor 29 tahun 2004 (UUPK) yaitu melakukan registrasi dokter dan dokter gigi, mengesahkan standar pendidikan profesi dokter dan dokter gigi dan melakukan pembinaan terhadap penyelenggaraan praktik kedokteran yang dilaksanakan bersama lembaga terkait dalam rangka meningkatkan mutu pelayanan medis. 
p-ISSN: 0853-4470 - Vol. 01, No. 02 (2018), pp. 29-40

Dalam menjalankan fungsi dan tugas sebagaimana dimaksud dalam pasal 7 UUPK di atas, KKI mempunyai wewenang sesuai pasal 8 UUPK yaitu menyetujui dan menolak permohonan registrasi dokter dan dokter gigi. Menerbitkan dan mencabut surat tanda registrasi. Mengesahkan standar kompetensi. Melakukan pengujian terhadap persyaratan registrasi dokter dan dokter gigi. Mengesahkan penerapan cabang ilmu kedokteran dan kedokteran gigi. Melakukan pembinaan bersama terhadap dokter dan dokter gigi mengenai pelaksanaan etika profesi yang ditetapkan oleh organisasi profesi. Melakukan pencatatan terhadap dokter dan dokter gigi yang dikenakan sanksi oleh organisasi profesi atau perangkatnya karena melanggar ketentuan etika profesi.

Perangkat regulasi yang mendukung KKI dalam mempublikasikan informasi didukung oleh sejumlah aturan sebagai berikut:

\section{Perangkat Regulasi Yang Mendukung KKI Dalam Mempublikasikan Informasi}

\begin{tabular}{|l|l|}
\hline \multicolumn{1}{|c|}{ Peraturan } & \multicolumn{1}{c}{ Tentang } \\
\hline UU No 29 Tahun 2004 & $\begin{array}{l}\text { Tentang Praktik Kedokteran (Lembaran Negara Republik } \\
\text { Indonesia Tahun 2004 Nomor 116, Tambahan Lembaran } \\
\text { Negara Republik Indonesia Nomor 4431); }\end{array}$ \\
\hline Undang-Undang Nomor 14 Tahun 2008 & $\begin{array}{l}\text { Tentang Keterbukaan Informasi Publik (Lembaran Negara } \\
\text { Republik Indonesia Tahun 2008 Nomor 61, Tambahan } \\
\text { Lembaran Negara Republik Indonesia Nomor 4846); }\end{array}$ \\
\hline $\begin{array}{l}\text { Undang-Undang Republik Indonesia Nomor 11 } \\
\text { Tahun 2008 }\end{array}$ & $\begin{array}{l}\text { Tentang Informasi dan Transaksi Elektronik (Lembaran } \\
\text { Negara Republik Tahun 2008 Nomor 58, Tambahan } \\
\text { Lembaran Negara Republik Indonesia Nomor 4843; }\end{array}$ \\
\hline $\begin{array}{l}\text { Instruksi Presiden Republik Indonesia Nomor 3 } \\
\text { Tahun 2004 }\end{array}$ & $\begin{array}{l}\text { Tentang Kebijakan dan Strategi Nasional Pengembangan e- } \\
\text { Government; }\end{array}$ \\
\hline $\begin{array}{l}\text { Peraturan Konsil Kedokteran Indonesia Nomor } 6 \\
\text { Tahun 2011 }\end{array}$ & $\begin{array}{l}\text { Tentang Registrasi Dokter dan Dokter Gigi (Berita Negara } \\
\text { Republik Indonesia Tahun 2012 Nomor 354); }\end{array}$ \\
\hline $\begin{array}{l}\text { Peraturan Konsil Kedokteran Indonesia Nomor 18 } \\
\text { Tahun 2014 }\end{array}$ & $\begin{array}{l}\text { tentang Sistem Informasi Registrasi Dokter dan Dokter Gigi } \\
\text { Berbasis Elektronik, }\end{array}$ \\
\hline $\begin{array}{l}\text { Keputusan Menteri Kesehatan Nomor } \\
\text { 192/MENKES/SK/VI/2012 }\end{array}$ & $\begin{array}{l}\text { Tentang Roadmap Rencara Aksi Penguatan Sistem Informasi } \\
\text { Kesehatan Indonesia; }\end{array}$ \\
\hline $\begin{array}{l}\text { Keputusan Menteri Komunikasi dan Informasi } \\
\text { Nomor 56/KEP/M.KOMINFO/12/2003 }\end{array}$ & tentang Panduan Manajemen Sistem Dokumen Elektronik) \\
\hline
\end{tabular}

Dari aturan-aturan tersebut di atas, maka Konsil Kedokteran Indonesia menyediakan Informasi khususnya terkait registrasi adalah dalam bentuk profil dokter dan dokter gigi secara umum. Profil dokter dan dokter gigi secara umum tersebut meliputi: (1) grafik perbandingan jumlah dokter, dokter gigi, dokter spesialis, dokter gigi spesialis per Wilayah Indonesia; (2) peta sebaran tempat praktik dokter dan dokter gigi di Indonesia; (3) grafik sebaran alumni institusi pendidikan kedokteran dan institusi pendidikan kedokteran gigi per Provinsi di Indonesia.

Selain itu Informasi pribadi dokter/dokter gigi juga dapat diinformasikan kepada publik apabila ada kaitannya dengan keselamatan pasien yaitu meliputi: (1) nama dokter, dokter gigi, dokter spesialis (2) okter gigi spesialis sesuai tertera dalam Surat Tanda Registrasi (STR); (3) jenis kelamin; (4) jenis kompetensi; (5) asal universitas pendidikan terakhir; (6) alamat praktik; (7) kewarganegaraan; (8) nomor STR dan masa berlakunya; (9) nomor Surat Izin Praktik (SIP) dan masa berlakunya.

Tetapi Konsil Kedokteran Indonesia juga berhak menolak memberikan informasi kepada publik karena ada informasi yang tidak dapat diberikan kepada publik atau informasi yang dikecualikan. informasi yang dikecualikan meliputi: (1) informasi yang dapat membahayakan 
negara; (2) informasi yang berkaitan dengan kepentingan perlindungan terhadap penyalahgunaan oleh pihak tertentu untuk kepentingan usaha; (3) informasi yang berkaitan dengan hak-hak pribadi; (4) informasi yang berkaitan dengan rahasia jabatan; dan/atau; (5) informasi publik yang diminta belum dikuasai atau didokumentasikan.

Informasi yang dikecualikan tersebut ada kaitannya dengan profil dokter dan dokter gigi secara khusus yaitu meliputi: (1) total jumlah SIR per tanggal kadaluwarsa, SIR baru, dan SIR Ulang per kompetensi dan propinsi/kabupaten/kota; (2) daftar nama SIR yang sudah kadaluwarsa per kompetensi; (3) jumlah total pengaduan disiplin yang diterima melalui e-Registrasi; (4) informasi khusus lain sesuai yang dibutuhkan.

Jadi walaupun Konsil Kedokteran Indonesia berkewajiban untuk membuka akses bagi setiap pemohon informasi publik untuk mendapatkan informasi tetapi ada juga beberapa informasi tertentu yang dikecualikan. Secara spesifik, data yang dibagikan pada publik dibedakan antara Informasi Publik Berkala, Informasi Publik Serta Merta, Informasi Publik Setiap Saat, Informasi Publik Kecuali (ketat terbatas dan rahasia).

Berikut rinciannya: Informasi Publik Berkala: (1) Profil Umum KKI, MKDKI, Set KKI; (2) Daftar Anggota KKI, MKDKI; (3) Daftar pejabat structural Sekretariat KKI; (4) Laporan Akuntabilitas Kinerja; (5) Profil dokter dan dokter gigi yang terregistrasi; (6) Profil data pribadi dokter dan dokter gigi yang terregistrasi; (7) Profil umum dokter dan dokter gigi yang diadukan ke MKDKI serta hasil keputusan terkait dugaan pelanggaran disiplin ilmu kedokteran dan kedokteraan gigi.

Informasi Publik Serta Merta (Spontan - Hajat Hidup): (1) Informasi terkait penyelenggaraan praktik kedokteran oleh dokter dan dokter gigi yang dapat mengancam keselamatan pasien; (2) Informasi terkait gangguan kelancaran pelaksanaan pemeriksaan dugaan pelanggaran disiplin ilmu kedokteran atau kedokteran.

Informasi Publik Setiap Saat: (1) Manual registrasi baru maupun ulang bagi dokter dan dokter gigi melalui media dalam jaringan (online); (2)Tata cara, persyaratan, dan biaya untuk permohonan registrasi; (3) Tata cara dan persyaratan pengaduan dugaan pelanggaran disiplin ilmu kedokteran dan kedokteran gigi ke MKDKI; (4) Berita umum terkait kegiatan KKI, MKDKI, dan Sekretariat KKI; (5) Buku terbitan KKI dalam bentuk e-book; (6) Standar dan maklumat pelayanan publik di KKI; (7) Tautan (hyperlink) ke situs kementerian/lembaga lain yang terkait penyelenggaraan praktik kedokteran; (8) Daftar Keputusan KKI; (9) Daftar Peraturan KKI.

Informasi Publik Kecuali - Ketat Terbatas: (1) Keputusan MKDKI atas hasil pemeriksaan dugaan pelanggaran displin ilmu kedokteran dan kedokteran gigi; (2) Keputusan KKI atas penegakan sanksi disiplin berdasarkan Keputusan MKDKI; (3) Profil umum dokter dan dokter gigi yang terregistrasi; (4) Profil data pribadi dokter dan dokter gigi yang terregistrasi; (5) Informasi jadwal persidangan MKDKI.

Informasi Publik Kecuali - Rahasia : (1) Seluruh dokumen atau berkas yang terkait proses penanganan dugaan pelanggaran disiplin; (2). Identitas lengkap dokter dan dokter gigi yang diadukan dan/atau yang terkena sanksi pelanggaran disiplin; (3). Identitas lengkap pengadu dan pihak-pihak yang diperiksa serta saksi ahli yang didengarkan keterangannya oleh MKDKI

\section{Upaya Menjaga Keamanan Informasi KKI}

Kejahatan siber pada sistem yang dimiliki institusi mungkin terjadi atas berbagai alasan, diantaranya: (1) Manakala security sistem tidak up-to-date, (2) ada kekurangan/kelemahan dari sistem, (3) ada kecanggihan pelaku dalam mengenali kekurangan/kelemahan sistem. Kejahatan siber juga bisa terjadi karena keisengan pelaku, biasanya untuk menunjukkan kemampuannya dalam meretas sistem; (4) kepentingan untuk memperoleh keuntungan, misalnya dengan 
memalsukan dokumen-dokumen yang tersimpan di dalam sistem; (5) kepentingan politik, misalnya melakukan teror dengan merusak dan mengacaukan system, (6) kepentingan ideologi, misalnya sebuah negara sedang berkonflik, hacker negara tersebut mendukung sikap negaranya dengan mengganggu situs-situs musuh negaranya, (7) kepentingan bisnis industri antivirus, misalnya dengan mengembangkan antivirus baru dengan cara secara aktif mempelajari berbagai sistem yang umum dipakai, lalu mereka memproduksi virus baru, sehingga produk mereka laku di pasaran (wawancara dengan Harman, praktisi teknologi informasi).

Atas peluang terjadinya kejahatan siber, maka KKI perlu melakukan penjagaan keamanan informasinya. Beberapa upaya telah dilakukan oleh KKI. Pertama, merujuk pada Salinan Peraturan Konsil Kedokteran Indonesia Nomor 18 Tahun 2014 tentang Sistem Informasi Registrasi Dokter dan Dokter Gigi Berbasis Elektronik, di pasal 27 dinyatakan bahwa kerjasama dalam pengaturan sistem pendukung jaringan e-Registrasi dikelola oleh administrator sistem yang terdiri dari: (1) Administrator Sistem e-Registrasi KKI yang mengelola keamanan informasi e-Registrasi, meliputi: Penjagaan terhadap keamanan dan perawatan data e-Registrasi yang berada dalam pengkalan data KKI; Menyempurnakan dan mengembangkan aplikasi dalam Situs Web KKI sesuai kebutuhan dalam lingkup nasional maupun dalam kaitan dengan kerjasama pertukaran informasi secara regional; Membuat berita acara penyerahan Kode Akses untuk dikelola oleh Administrator Sistem Informasi badan/organisasi terkait sebanyak jumlah pengguna yang akan mengakses aplikasi e-Registrasi dalam wilayah kerja masing-masing; Mengatur identitas dan hak akses pengguna yang akan memanfaatkan informasi publik maupun informasi yang dikecualikan di masing-masing mitra, (2) Administrator Sistem Informasi yang diberi kewenangan tertentu untuk menjaga keamanan informasi e-Registrasi dan pemanfaatannya, meliputi: Mengelola identitas pengguna yang diberi hak akses ke aplikasi dalam Situs Web KKI; Mendistribusikan Kode Akses ke pengguna sebagaimana dimaksud diatas.

KKI juga menggunakan sistem registrasi internal sebagai upaya menjaga keamanan informasi. Server dimiliki serta dioperasikan sendiri oleh KKI, dan belum berkolaborasi dengan organisasi atau institusi lain selain Pusat Data Kemenkes. Data e-registrasi KKI menggunakan ISO 9001: 2008 yaitu Sistem Manajemen Mutu dan Budaya Organisasi Pelayanan Publik. ISO 9001: 2008 Merupakan prosedur terdokumentasi dan praktek - praktek standar untuk manajemen sistem, yang bertujuan menjamin kesesuaian dari suatu proses dan produk (barang atau jasa) terhadap kebutuhan atau persyaratan tertentu, dimana kebutuhan atau persyaratan tertentu tersebut ditentukan atau dispesifikasikan oleh pelanggan dan organisasi.

Upaya lain untuk memperkuat keamanan data yang diproduksi KKI, misalnya STR, KKI menerapkan penomoran yang unik dengan tujuan untuk mencegah pemalsuan. Penomoran yang unik sebagai bentuk dari layanan keamanan berupa autentikasi dan integritas data dengan menggunakan sertifikat elektronik sebagai perwujudan good governance. Untuk itu pada tahun 2018, KKI melakukan kerjasama dengan Badan Siber dan Sandi Negara terkait pemanfaatan sertifikat elektronik pada sistem elektronik di Konsil Kedokteran Indonesia.

Kerjasama tersebut dilakukan sebagai bentuk dari penerapan kinerja yang diamanahkan melalui Undang-Undang Nomor 29 Tahun 2004 tentang Praktik Kedokteran (Lembaran Negara Republik Indonesia Tahun 2004 Nomor 116, Tambahan Lembaran Negara Republik Indonesia Nomor 4431); Undang Undang Nomor 11 Tahun 2008 tentang lnformasi dan Transaksi Elektronik (Lembaran Negara Republik Indonesia Tahun 2008 Nomor 58, Tambahan Lembaran Negara Republik Indonesia Nomor 4843); Peraturan Pemerintah Nomor 82 Tahun 2012 tentang Penyelenggaraan Sistem dan Transaksi Elektronik (Lembaran Negara Republik lndonesia f ahun 
2012 Nomor 189, Tambahan Lembaran Negara Republik Indonesia Nomor 5348); Peraturan Menteri Kesehatan Republik lndonesia Nomor 1442lMenkes/PERDU2005 tentang Organisasi dan Tata Kerja Sekretariat Konsil Kedokteran Indonesia; Peraturan Konsil Kedokteran lndonesia Nomor 18 Tahun 2014 tentang Sistem Informasi Registrasi Dokter dan Dokter Gigi Berbasis Elektronik (Berita Negara Republik Indonesia Tahun 2014 Nomor 319); dan Peraturan Kepala Lembaga Sandi Negara Nomor 15 Tahun 2016 tentang Organisasi dan Tata Kerja Balai Sertifikasi Elektronik (Berita Negara Republik lndonesia Tahun 2016 Nomor 1786).

Berdasarkan Peraturan Pemerintah RI No. 82 Tahun 2012 Tentang Penyelenggaraan Sistem dan Transaksi Elektronik, serta Peraturan Menteri No 36 Tahun 2014 Tentang Tata Cara Pendaftaran Sistem Elektronik, KKI berencana untuk mendaftarkan Sistem Penerbitan STRnya ke Kementerian Kominfo. Pelaksanaan rencana tersebut akan meningkatkan keamanan informasi pada sistem e-Registrasi KKI karena pendaftaran Sistem Elektronik menuntut standar keamanan informasi yang mengacu pada Peraturan Menteri Komunikasi dan Informastika No 4 Tahun 2016 tentang Sistem Manajemen Pengamanan Informasi.

Dalam mengelola keterbukaan informasi publik, Konsil Kedokteran Indonesia sebagai lembaga negara harus dapat mempertanggungjawabkan kepada masyarakat dan mempertimbangkan kebaikan bagi profesi kedokteran dan kedokteran gigi, sebagai bentuk jaminan hak asasi manusia (HAM). Pandangan Alasdair Roberts yang disampaikan pada konferensi The Carter Center's Transpency for Growth (1999) terkait akses terhadap informasi pemerintah bagi publik, merupakan alat untuk mempromosikan partisipasi politik. Akses ini diperlukan sebagai realisasi dari hak dasar kebebasan berpendapat dan ekspresi yang dijamin dalam Deklarasi Perserikatan Bangsa-Bangsa tentang Hak Asasi Manusia, dan tentunya juga sejalan dengan konstitusi nasional.

Akses terhadap informasi yang dibuka oleh lembaga negara sangat penting bagi masyarakat yang menyadari hak dasar mereka untuk berpartisipasi dalam mengatur negara mereka dan hidup dibawah sistem yang dibangun berdasarkan persetujuan dari warga negara. Selain itu, partisipasi politik tidak dapat dilaksanakan secara efektif tanda adanya keterbukaan informasi dari lembaga negara atau lembaga pemerintahan (Roberts, 1999).

Keterbukaan informasi publik, tidak sepenuhnya memberi kesempatan pada publik untuk mengakses seluruh informasi, namun kriteria seperti Informasi Publik Berkala, Informasi Publik Serta Merta, Informasi Publik Setiap Saat, Informasi Publik Kecuali (ketat terbatas dan rahasia), memang diperlukan. Penelitian Irianto dan Ispriyarso (2016) mengenai informasi publik di Perbankan, menunjukkan bahwa tidak serta merta semua informasi dapat dibagikan mengingat informasi tersebut dapat saja bertentangan dengan prinsip etika dan produk hukum lainnya, berbagai benturan kepentingan perlu mendapat perhatian seksama terutama terkait informasi kedokteran yang ketika terjadi kesalahan, dapat membahayakan kehidupan manusia.

Kebutuhan KKI untuk mengawal keterbukaan informasi publik secara proporsional dan tidak membahayakan masyarakat, secara positif didukung dalam Undang-Undang No 14 tahun 2008 Pasal 6 (1) yang menyebut bahwa Badan Publik berhak menolak memberikan informasi yang dikecualikan sesuai dengan ketentuan peraturan perundang-undangan. (2) Badan Publik berhak menolak memberikan Informasi Publik apabila tidak sesuai dengan ketentuan peraturan perundangundangan. (3) Informasi Publik yang tidak dapat diberikan oleh Badan Publik, sebagaimana dimaksud pada ayat (1) adalah: a. informasi yang dapat membahayakan negara; b. informasi yang berkaitan dengan kepentingan perlindungan usaha dari persaingan usaha tidak sehat; c. informasi yang berkaitan dengan hak-hak pribadi; d. informasi yang berkaitan dengan rahasia jabatan; dan/atau e. Informasi Publik yang diminta belum dikuasai atau didokumentasikan. Dengan 
demikian meski, transparansi merupakan hak dasar manusia (Birkenshaw 2006; Florini, 2007, Scholtes, 2012; Ruijer, 2013), namun tidak semua informasi dapat diberikan secara terbuka dengan dasar pertimbangan untuk menjaga kepentingan lainnya.

Selanjutnya, terkait penjagaan dalam keamanan informasi, terutama terkait penjagaan agar tidak ada pihak memasuki jaringan tanpa adanya kewenangan (cybertrepass); perusakan yang menganggu jaringan pelayanan seperti menambah, mengurangi, mengubah data atau instruksi pada program secara tidak sah (destructive cybercrimes); serta kejahatan lain yang oleh Shinder (2002) disebut sebagai kejahatan komputer tanpa kekerasan, KKI secara aktif telah melakukan upaya seperti yang telah dijelaskan diatas. Meski demikian, masih diperlukan penelaahan dan penjagaan yang lebih baik terhadap keamanan informasi yang dimiliki oleh KKI.

\section{KESIMPULAN}

Penelitian ini menggali informasi apa yang disampaikan oleh lembaga negara (KKI/komunikator) kepada publik (masyarakat) sebagai pengejewantahan dari transparansi dari lembaga negara pada masyarakat. Transparansi ini juga wujud dari demokrasi sebagai bentuk dari hak atas informasi yang dijamin oleh konstitusi.

Informasi yang disampaikan diharapkan dapat menjadi fondasi bagi pengambilan keputusan publik, mendorong partisipasi masyarakat dalam proses pengambilan kebijakan publik, meningkatkan peran aktif masyarakat dalam pengambilan kebijakan publik dan pengelolaan Badan Publik yang baik; mewujudkan penyelenggaraan negara yang baik, yaitu yang transparan, efektif dan efisien, akuntabel serta dapat dipertanggungjawabkan; mengetahui alasan kebijakan publik yang mempengaruhi hajat hidup orang banyak; mengembangkan ilmu pengetahuan dan mencerdaskan kehidupan bangsa; dan/atau meningkatkan pengelolaan dan pelayanan informasi di lingkungan Badan Publik untuk menghasilkan layanan informasi yang berkualitas.

Informasi yang disampaikan oleh KKI dalam mendukung adanya Undang-Undang Keterbukaan Informasi Publik dikelola dengan sebaik mungkin sehingga tidak bertentangan dengan prinsip etika dalam profesi kedokteran. Disamping itu, penjagaan terhadap keamanan data sistem elektronik yang dimiliki oleh KKI perlu senantiasa mendapat perhatian sebaik-baiknya, sesuai tujuan dari didirikannya KKI, yaitu perlindungan pada masyarakat.

\section{Ucapatan Terimakasih}

Terima kasih kepada Komisioner Konsil Kedokteran Indonesia, Majelis Kehormatan Disiplin Kedokteran Indonesia, Staf Sekretariat dan NHD, sebagai praktisi IT, yang telah berkenan memberikan penjelasan dan arahan terkait informasi-informasi yang bermanfaat bagi penelitian ini.

\section{Daftar Pustaka}

Cyber attack on Singapore health database steals details of $1.5 \mathrm{~m}$ including prime minister; The Telegraph, Matthew Field, 20 Juli 2018. https://www.telegraph.co.uk/news/2018/07/20/cyber-attacksingapore-health-database-steals-details-15m-including/

Deklarasi Umum Hak Asasi Manusia (DUHAM) Pasal 19; UU No. 39 Tahun 1999 tentang Hak Asasi Manusia, pasal 14; UU No. 12 Tahun 2005 tentang Ratifikasi Kovenan Internasional Hak-hak Sipil Politik. Pasal 19, Ayat 2

Fisher, B. Aubrey. 1986. Teori-teori Komunikasi. Penyunting: Jalaluddin Rakhmat. Penerjemah: Soejono Trimo. Bandung: Remaja Rosdakarya.

Davis, Gordon B. 1995. Sistem Informasi Manajemen, PT. Pustaka Binaman Pressindo. 
p-ISSN: 0853-4470 - Vol. 01, No. 02 (2018), pp. 29-40

http://www.southeastasia.atkearney.com/documents/766402/15958324/Cybersecurity+in+ASEAN\%E2\%80 \%94An+Urgent+Call+to+Action.pdf/ffd3e1ef-d44a-ac3a-9729-22afbec39364

https://www.komisiinformasi.go.id/uploads/files/Ketua\%20KIP\%20\%20Resolusi\%20ICIC\%20IX\%202015 $\% 20-\% 20$ Chile.pdf

Laura Neuman (editor). 2002. Access to Information: A Key To Democracy. USA: The Carter Center https://www.cartercenter.org/documents/1272.pdf

Lasswell, H. 1948. "The Structure Function of Communication in Society", The Communication of Ideas. Institute for Religious and Social Studies. New York.

Mc.Luhan, Marshall. 1992. The Global Village: Transformations in World Life and Media in the $21^{\text {st }}$ Century; Oxford University Press. USA (first published 1989)

Miles, M.B. \& Huberman, A.M. 1994. Qualitative Data Analysis. London : Sage Publishers.

Mulyana, Dedy. 2001. Metodologi Penelitian Kualitatif (Paradigma Baru Komunikasi dan Ilmu Sosial Lainnya). Bandung: Remaja Rosdakarya.

Nupikso. 2015. Implementasi Keterbukaan Informasi Publik dalam Website Pemerintah Daerah. Journal article Jurnal Ilmu Pengetahuan dan Teknologi Komunikasi. Publisehd oleh BPSDMP Kominfo Yogyakarta

Peraturan Konsil (Perkonsil) Nomor 18 Tahun 2014. Tentang Sistem Informasi Registrasi Dokter dan Dokter Gigi Berbasis Elektronik

Retnowati, Endang. 2012. Keterbukaan Informasi Publik dan Good Governance (Antara Das Sein Dan Das Sollen). Jurnal Perspektif Volume 27(1.

Republik Indonesia. 1945. Undang-Undang Dasar. Jakarta: Sekretariat Negara.

Republik Indonesia. 2008. Undang-Undang Nomor 14. Keterbukaan Informasi Publik. Jakarta: Sekretariat Negara.

Ruijer, H.J.M. (Erna). 2013. Proactive Transparency and Government Communication in the USA and the Netherlands. Virginia Commonwealth University VCU Scholars Compass. diakses Oktober 2013

Roberts, Alasdair. 1999. Access To Government Information: An Overview Of Issues. dalam A Key To Democracy. Edited: Laura Neuman. 2002. The Carter Center. https://www. cartercenter.org/documents/1272.pdf

Shinder, Debra Littlejohn. 2002. Scene of the Cybercrime: Computer Forensics Handbook. Syngress Publishing,Inc.

Toffler, Alvin. 1980. The Third Wave. London: Pan Books Ltd in association with William Collins Sons \& Co. Ltd. 